\author{
Олексій Пластун, Юлія Сльнікова, Асіят Шелюк, \\ Анна Воронцова, Аліна Артеменко
}

Сумський державний університет

Украӥна

\title{
РОЛЬ ДЕРЖАВНОЇ ІНВЕСТИЦЙНОЇ ПОЛІТИКИ ТА ВІДПОВІДАЛЬНОГО ІНВЕСТУВАННЯ У ФІНАНСУВАННІ СТАЛОГО РОЗВИТКУ
}

\begin{abstract}
Мета. Метою статті $\epsilon$ дослідження ролі державної інвестиційної політики у фінансуванні сталого розвитку та конщепщій відповідального інвестування як прикладного інструментарію та механізму їі реалізаџії.

Методологія / методика / підхід. Роль державної інвестиційної політики у фінансуванні сталого розвитку досліджено за допомогою структурно-функціонального аналізу, який дозволив провести ї деталізацію за секторами та напрямами фінансових потоків і стадіями інвестииійного ланияюга, напрямами інтервенцій державної інвестиційної політики, а також органами, щяо ї̈ реалізують.

Результати. У статті досліджені концепції відповідального інвестування як прикладного інструментарію та механізму реалізації державної інвестиційної політики. Визначений зв'язок між: ESG - критерії оичінки (скринінгу) інвестиційних рішень та категоріями фінансів сталого розвитку. Визначено співвідношення інвестиційних ресурсів, напряму фінансових потоків $і$ стадій інвестиційного ланцңюга, та роль державної інвестиційної політики в межах фінансової системи сталого розвитку за секторами економіки та ї̈ ключовими напрямами.
\end{abstract}

Орихінальність / наукова новизна. Проаналізовані аспекти й заходи державної інвестииійної політики за Цілями сталого розвитку. На основі изього розроблено дворівневий теоретико-методичний підхід до визначення ролі державної інвестиційної політики та місия механізму відповідального інвестування у формуванні фінансової системи, зорієнтованої на досягнення иих Цілей. Визначені напрями державної інвестиційної політики передусім узгоджуються з пріоритетними напрямами реформування фінансових систем краӥн світу на засадах сталого розвитку та асоиійовані з певними суб'єктами інвестиційного ланцюга $з$ огляду на їх релевантність і пріоритетність, а також відсутність у межах національної фінансової інфраструктури та регуляторних норм у сфері інвестування.

Практична цінність / значущість. Запропоновано найбільш пріоритетні напрями державної інвестиційної політики в контексті відповідального механізму ї̈ реалізації 3 урахуванням найбільш релевантних для відповідальних інвесторів Цілей сталого розвитку та ESG - критеріїв. Ці заходи можуть бути використані для вдосконалення політики держсавних інвестицій ї̈ регуляторами.

Ключові слова: ESG - критерії, державна інвестиційна політика, відповідальне інвестування, Цілі сталого розвитку, фінанси сталого розвитку. 


\section{THE ROLE OF PUBLIC INVESTMENT POLICY AND RESPONSIBLE INVESTMENT IN SUSTAINABLE DEVELOPMENT FINANCING}

Purpose. The aim of the article is to study the role of public investment policy in financing sustainable development and the concepts of responsible investment as an applied tool and mechanism for implementing this policy.

Methodology / approach. The role of the public investment policy in financing sustainable development was investigated within the structural-and-functional analysis, which allowed investigating it by sectors and directions of financial flows and stages of the investment chain, directions of interventions, as well as bodies implementing this policy.

Results. The article explores the concepts of responsible investing as an applied tool and mechanism for implementing public investment policy. The relationship between ESGs - investment decision criteria and sustainable finance categories - is identified. The relationship between investment resources, the direction of financial flows and stages of the investment chain, and the role of public investment policy within the financial system of sustainable development by economic sectors and its key directions are determined.

Originality / scientific novelty. Aspects and measures of the public investment policy according to the Sustainable Development Goals are analysed. Based on this, a two-level theoretical and methodological approach to determining the role of public investment policy and the place of responsible investing mechanism in the formation of a financial system oriented towards the achievement of these goals is developed. The identified areas of public investment policy are first and foremost consistent with the priority directions of reforming the financial systems of the countries of the world on the principles of sustainable development, and associated with certain entities of the investment chain in view of their relevance and priority, as well as the lack within the national financial infrastructure and regulatory framework.

Practical value / implications. The most priority directions of the public investment policy in the context of the responsible mechanism of its implementation, the most relevant for responsible investors Sustainable Development Goals and ESG - criteria are offered. These measures can be used to improve public investment policy by its regulators.

Key words: ESG criteria, public investment policy, responsible investment, sustainable development goals, sustainable development finance.

Постановка проблеми. Знаковими подіями, що зумовлюють зміну вектора інвестиційної політики країн світу, $є$ три саміти, що відбулися на міжнародному рівні у 2015 р.: саміт в Аддіс-Абебі у липні, присвячений фінансуванню сталого розвитку; саміт у Нью-Йорку у вересні, присвячений формуванню системи глобальних Цілей сталого розвитку (ЦСР) до 2030 р. та конференція Сторін (COP21) Рамкової конвенції ООН щодо зміни клімату в Парижі у грудні, присвячена напрацюванням спільного порядку денного зі скорочення викидів парникових газів. Ці події визначають новий формат співробітництва у фінансуванні сталого розвитку на найвищому рівні. Його напрацювання $\epsilon$ логічним продовженням перебудови інвестиційних політик країн світу на 


\section{Agricultural and Resource Economics \\ www.are-journal.com}

засадах сталого розвитку, які визначені у главі 33 Порядку денного 21 (1992 р.) [1] та главі Х Йоханесбурзького плану (2002 р.) [2], а також параграфах 253-268 результатів конференції ООН зі сталого розвитку (2012р.) «Майбутнє, якого ми прагнемо».

Інтеграція зусиль світового співтовариства у сфері інвестування в сталий розвиток зумовлена потребою в мобілізації та ефективному використанні значних фінансових ресурсів різного виду та походження для підтримки країн, що розвиваються, на шляху до сталого розвитку та досягнення ЦСР [3]. На найвищому організаційному рівні вона відбувається в рамках форумів для фінансування розвитку (FfD forum) та ЦСР, які проводилися щорічно у 20162018 рр. При цьому, за різними оцінками, фінансування ЦСР потребує від 4,7 до 6,7 трлн євро щорічно з 2016 до 2030 рр. [4], у той час як поточний рівень інвестицій у цьому напрямі становить лише половину від необхідного - близько 2,8 трлн євро. Подолання інвестиційного розриву у фінансуванні ЦСР, у першу чергу, виступає основним завданням для інвестиційних політик у різних країнах, які мають створити основу для функціонування фінансових систем нового типу, націлених на мобілізацію, акумуляцію, трансмісію та алокацію інвестиційних ресурсів для сталого розвитку.

Аналіз останніх досліджень і публікацій. Розгляд ролі державної інвестиційної політики (ДІП) у забезпеченні фінансування сталого розвитку та місця відповідального інвестування (BI) в ній нерозривно пов'язаний із дослідженням сутності та особливостей ДІП у цих умовах. Тому цьому питанню присвячено праці багатьох українських науковців. Зокрема, впровадження концепції відповідального ведення бізнесу (КСВ) на рівні підприємств досліджували I. М. Вигівська [5], М. С. Дейч [6], Т. Р. Антошко [7], Н. Л. Огороднікова [8]; особливості реалізації ДІП: А. А. Пересада [9], Т. В. Максимова [10], Г. О. Федоров [11], А. О. Ільїна [12], С. Г. Артемов [13]; формування теоретико-методологічного підгрунтя ВI в Україні: Т. П. Плішка [14], М. М. Ігнатенко [15], С. В. Рудейчук [16], Н. Г. Панченко [17], I. С. Шкура [18], Т. В. Романьок [19], Д. В. Леус [20], Л. П. Петрашко [21], Ю. В. Лазар [22; 23], О. В. Музиченко [24].

Питанню сталого фінансування присвячено праці багатьох зарубіжних науковців. Зокрема, проблему розуміння взаємозв'язків між державними інвестиціями та державним боргом у контексті сталого фінансування сталого розвитку, а також моделювання альтернативних моделей фінансування інвестицій досліджували I. Ari, М. Кос [25; 26]; роль фінансів у досягненні сталості вивчали S. Bose, G. Dong, A. Simpson [27]. Моделям бізнесу для сталого фінансування та пошуку відповіді на запитання про те, як створити більш сталі фінансові системи, присвячено роботи M. La Torre та ін. [28], M. Ziolo та ін. [29]. Різні аспекти сталого та відповідального інвестування досліджували M.-L. Tseng та ін. [30], M. Méndez-Suárez та ін. [31], T. A. Grzeszczyk, M. Waszkiewicz [32], J. Sandberg, D. Rönnegard [33], S. Blakstad, R. Allen [34], J. Kew, C. Krosinsky [35], M. A. Camilleri [36], S. Bose та ін. [37]. 


\section{Agricultural and Resource Economics \\ www.are-journal.com}

Теоретичне обгрунтування ВI як механізму реалізації ДІП лежить у площині дослідження сутності та особливостей доволі різнорідних механізмів. Думки науковців відзначаються плюралізмом не лише щодо набору елементів такого механізму, але й їхнього сутнісного наповнення (правові, економічні, інформаційні, мобілізаційні, фінансові та ін. механізми) і термінологічної визначеності. Разом із тим, поява нових інвестиційних механізмів, продуктів i технологій, які інтегруються в традиційну практику функціонування фінансових ринків, створює нові виклики для усталеної практики їх регулювання з боку державних інституцій і вимагає адекватного реагування засобами нової інвестиційної політики в умовах фінансування сталого розвитку та його Цілей.

Метою статті $\epsilon$ дослідження ролі ДІП у фінансуванні сталого розвитку та концепцій ВІ як прикладного інструментарію та механізму ії реалізації.

Виклад основного матеріалу дослідження. Дослідження концепції ВI як прикладного інструментарію та механізму реалізації ДІП лежить у межах більш широкого поняття - фінансів сталого розвитку як концепції, яка описує цілі, суб'єкти, об'єкти інвестицій, способи формування та використання інвестиційних ресурсів, прийоми, методи й технології прийняття інвестиційних рішень в економіці сталого розвитку чи в циркулярній економіці. Така широка концепція визначається як із використанням ESG - критеріїв (інтегрування ESG критеріїв) у фінансові рішення; фінанси, що стимулюють сталий економічний, екологічний і соціальний розвиток [38]; фінанси, що стосуються будь-якої фінансової послуги, що інтегрує ESG - критерії в бізнес та інвестиційні рішення 3 метою вигоди як клієнтів, так і суспільства в цілому [39; 40], а також більш традиційних понять «цінності», «стабільності». Зв'язок між ESG - критеріями прийняття інвестиційних рішень та категоріями фінансів сталого розвитку можна простежити на рис. 1.

\begin{tabular}{|c|c|c|c|}
\hline \multicolumn{4}{|c|}{ Критерії } \\
\hline \multicolumn{2}{|c|}{ Екологічні (Environmental, E) } & Соціальні (Social, S) & Управлінські (Governance, G) \\
\hline $\begin{array}{c}\text { Зменшення викидів } \\
\text { парникових газів, } \\
\text { нівелювання зміни } \\
\text { клімату }\end{array}$ & \multirow{2}{*}{$\begin{array}{l}\text { Інші екологічні } \\
\text { аспекти } \\
\text { (підтримка } \\
\text { біорізноманіття, } \\
\text { поводження } 3 \\
\text { відходами }\end{array}$} & \multirow{2}{*}{$\begin{array}{c}\text { Сприяння реалізації } \\
\text { цінностей громадян- } \\
\text { ського суспільства, } \\
\text { досягнення } \\
\text { очікуваного впливу в } \\
\text { соціальній сфері }\end{array}$} & \multirow{2}{*}{$\begin{array}{c}\text { Упровадження практик } \\
\text { корпоративного управління, } \\
\text { заснованих на прозорості, } \\
\text { диверсифікації, збалансуван- } \\
\text { ні фінансової ефективності й } \\
\text { інших критеріїв }\end{array}$} \\
\hline Кліматичні фінанси & & & \\
\hline \multicolumn{2}{|c|}{ Зелені фінанси } & Соціальні фінанси & \\
\hline \multicolumn{3}{|c|}{ Змішані (соціально-екологічні фінанси (Blended finance) } & \\
\hline \multicolumn{4}{|c|}{ Фінанси сталого розвитку (Sustainable finance) } \\
\hline
\end{tabular}

Рис. 1. Категорії фінансів сталого розвитку за критеріями прийняття відповідальних інвестиційних рішень

Джерело: складено авторами.

Через: ESG - критерії оцінки (скринінгу) інвестиційних рішень (як концепція та середовище реалізаціі) тісно пов'язані з відповідальним інвестуванням (як механізмом і методичним інструментарієм фінансування ЦСР) (табл. 1). 


\section{Agricultural and Resource Economics \\ www.are-journal.com}

Поява нових інвестиційних механізмів, продуктів i технологій, які інтегруються в традиційну практику функціонування фінансових ринків створює нові виклики для усталеної практики їх регулювання 3 боку державних інституцій і вимагає адекватного реагування засобами нової інвестиційної політики в умовах фінансування сталого розвитку та його Цілей.

Таблиия 1

Інвестиційні механізми за типами фінансової системи та сукупністю критеріїв

\begin{tabular}{|c|c|c|c|}
\hline Інвестиційний механізм & Тип фінансової системи & $\begin{array}{l}\text { Фінансова } \\
\text { дохідність }\end{array}$ & $\begin{array}{c}\text { ESG - } \\
\text { критеріï }\end{array}$ \\
\hline Традиційний & Традиційні фінанси & + & - \\
\hline $\begin{array}{l}\text { Соціально відповідальне } \\
\text { інвестування (Socially } \\
\text { Responsible Investment - SRI) }\end{array}$ & Соціальні фінанси & - & + \\
\hline «Зелені» інвестиції & $\begin{array}{l}\text { Кліматичні, } \\
\text { «зелені» фінанси }\end{array}$ & - & + \\
\hline Імпакт - інвестування & Змішані фінанси, соціальні фінанси & $+/-$ & $+/-$ \\
\hline $\begin{array}{l}\text { ESG та ЦСР - інвестування } \\
\text { (Sustainable and Responsible } \\
\text { Investment - SRI) }\end{array}$ & Фінанси сталого розвитку & + & + \\
\hline
\end{tabular}

Джерело: складено авторами.

Потреба у формуванні ДІП, націленої на досягнення ЦСР засобами ВІ лежить у площині нівелювання ринкових провалів для повноцінного виконання соціально-економічних функцій держави в умовах сталого розвитку, а також упереджень приватного бізнесу щодо неефективності відповідальних механізмів інвестування для досягнення його Цілей. У цьому зв'язку завдання ДІП (поліпшення інвестиційного клімату держави, зростання обсягів іноземних інвестицій, формування середовища та відповідних видів забезпечення для залучення інвестиційних ресурсів реалізації пріоритетних національних інвестиційних проектів) мають розглядатися через призму сталого розвитку й носити відповідальний характер, заснований на його цінностях і Цілях.

При цьому сприяння досягненню ЦСР засобами ДІП автоматично включає традиційні напрями: стимулювання економічного зростання, нарощування ВВП, забезпечення повної зайнятості через включення економічної компоненти сталого розвитку. А врахування соціального та екологічного складників сталого розвитку робить нову ДІП більш комплексною з огляду на:

1) масштаб охоплення інвестиційних сфер (не лише, пріоритетних галузей національної економіки, визначених у Господарському кодексі України, але й інкорпорації цінностей сталого розвитку шляхом їх інвестиційної підтримки в усі галузі (сектори, сегменти (малий, середній, великий бізнес) економіки для підвищення їх конкурентоспроможності в такий спосіб);

2) джерела та потоки інвестиційних ресурсів усебічного походження (внутрішні, зовнішні, державні, приватні, міжнародних донорів тощо);

3) рамкові умови для формування ефективного й прозорого інвестиційного 


\section{Agricultural and Resource Economics \\ www.are-journal.com}

середовища фінансової системи, де всі суб'єкти, продукти, відносини та стадії інвестиційного ланцюга здійснюються з урахуванням ЦСР засобами ВI.

BI у контексті реалізації ДІП $є$ новим комплексним механізмом іiі наскрізного переосмислення, формування, здійснення та удосконалення, передусім (ознаки виокремлено за О. А. Мельниченко [41]):

1) за метою регуляторного впливу - створення достатнього пулу ресурсів для фінансування сталого розвитку та його Цілей;

2) за формою регуляторного впливу - використання не лише інструментів державного чи корпоративного управління інвестиційного процесу, а значної кількості нових солідарних і партнерських форм відповідального інвестування;

3) за етапами регуляторного впливу: формування, реалізації та удосконалення інвестиційної політики відповідального типу в умовах формування фінансової системи та ДІП, націлених на фінансування сталого розвитку та його Цілей;

4) за способом регуляторного впливу: адміністративний; економічний; нормативно-правовий; організаційний; соціально-психологічний види забезпечення притаманні і ВІ як механізму ДІП.

За об'єктом регуляторного випливу: територія (держава, регіон, населений пункт); галузь чи сфера діяльності; суб'єкт господарювання; рух інвестиційних ресурсів; відсутня різниця між традиційним та відповідальним механізмами ДІП як за рівневою ознакою (глобальний; національний; регіональний; локальний), так і за етапами інвестиційного процесу (розробка інвестиційного проекту; залучення інвестицій; використання інвестицій; реінвестиції та/чи виведення із проекту прибутку на інвестиції; виведення інвестицій). Не відрізняються від традиційного механізму й стадії інвестиційного ланцюга (мобілізація, акумуляція, трансмісія, алокація та відшкодування інвестиційних ресурсів). У межах відповідального механізму змінюється лише їх змістовне наповнення орієнтація на інвестиційні ресурси для сталого розвитку та його Цілей.

Таким чином, традиційний та відповідальний механізми реалізації ДІП мають досить багато спільних процесних характеристик. У той же час, у ході формування ВI як механізму ДІП акцент зміщується, зважаючи на нову роль ДІП, спрямовану на підтримку фінансової системи нового типу, й безпосередньо стосується окремих її суб'єктів.

Ураховуючи європейський досвід ДІП [42] та наднаціональні ініціативи [43; 44] ролі держави (в особі органів відповідальних за інвестиційну політику) при iii реалізації за цими напрямами можна конкретизувати як «ініціатора», «медіатора» та «акумулятора»:

1) Ініціатор

a) створення кодексів, положень i регуляторних документів щодо окреслення прав, обов'язків, напрямів взаємодії BI, розкриття інформації зі сталого розвитку підприємствами;

б) формування рамкових умов регулювання та моделі функціонування ринку ВI (дизайн основних компонентів моделі: орієнтири, рейтингові продукти, 


\section{Agricultural and Resource Economics \\ www.are-journal.com}

провайдери інформації, інтегрування ESG чинників у депозитарну, клірингову, біржову інфраструктуру та наглядові інститути), системи інвестиційних завдань ЦСР;

2) Медіатор

a) створення умов і прозорого середовища для здійснення інвестицій в ЦСР - мотивація, акумуляція, алокація відповідальних інвестицій з урахуванням національних інтересів і громадянського суспільства та майбутніх поколінь;

б) глобальний та національний діалог і мультистейкхолдерські партнерства (уряд, підприємства, інвестори, громади, міжнародні донори) щодо формування стратегій і дорожніх карт інвестування у ЦСР;

в) сприяння прозорості та підзвітності бізнес-середовища як основи для прийняття інвестиційних рішень, стабільності роботи ринків капіталу;

3) Акумулятор

a) спонсорування фондів інвестування в ініціативи сталого розвитку, зокрема й фондів суверенного добробуту та проектів державно-приватного партнерства;

б) активізація взаємодії та формування інвестиційних ресурсів у сфері ВІ та сталого розвитку з міжнародними донорами через механізми офіційної допомоги розвитку (Official Development Assistance - ODA), запровадження «зелених» іпотек, облігацій, облігацій катастроф, енергетичних облігацій та ін., інвестиційних продуктів, які можуть виступати каталізаторами інвестиційного ланцюга ВI;

в) створення основи для формування багатосторонніх і національних банків розвитку для мобілізації інвестиційних ресурсів із приватного сектора.

Ураховуючи зазначені напрями, та спираючись на традиційне структурування інвестиційного ланцюга за:

1) суб' єктами (Приватні та інституційні інвестори, Держава (в особі органів реалізації ДІП), Міжнародні фінансові, донорські та наглядові організації, Неурядові організації, Компанії, Громадськість);

2) стадіями (Мобілізація, Акумуляція, Трансмісія, Алокація інвестиційних ресурсів та Відшкодування вкладених інвестицій);

3) секторами (Домогосподарства, Реальний і Фінансовий сектори) окреслимо окремі аспекти в іiі побудові, які деталізовано за секторами та напрямами фінансових потоків і стадіями інвестиційного ланцюга, напрямами інтервенцій ДІП та секторами, а також органами, що реалізують ДІП.

Визначені напрями ДІП передусім узгоджуються 3 пріоритетними напрямами реформування фінансових систем країн світу на засадах сталого розвитку та асоційовані $з$ певними суб' єктами інвестиційного ланцюга 3 огляду на їх релевантність і пріоритетність, а також відсутність у межах національної фінансової інфраструктури та регуляторних норм у сфері інвестування. Зокрема, найбільш пріоритетними напрямами ДІП у контексті відповідального механізму iï реалізації запропоновано такі:

1) для приватних та інституційних інвесторів: 


\section{Agricultural and Resource Economics \\ www.are-journal.com}

a) забезпечення прозорості, орієнтирів і методології регулювання ВI;

б) створення суверенного фонду добробуту для реалізації ДІП на засадах ВI;

в) розробка критеріїв скринінгу та прийняття рішень у ВI.

2) для компаній і громадськості, неурядових організацій:

a) здійснення ДІП за найбільш пріоритетними ЦСР;

б) імпакт-інвестування в найбільш важливі проекти ЦСР та стимулювання ВI у ці проекти;

в) підвищення мотивації до інтегрування ЦСР у діяльність і проекти компаній.

3) для органів, відповідальних за реалізацію інвестиційної політики:

а) формування інвестиційної політики, iї моделей, детермінант;

б) моніторинг і подолання інвестиційного гепу (GAP - розрив, дисбаланс) інвестиційних ресурсів для фінансування проектів сталого розвитку та ЦСР.

4) для міжнародних фінансових, донорських і наглядових організацій:

a) упорядкування нормативного ландшафту BI;

б) оцінювання інвестиційної привабливості галузей, регіонів і країн для ВI.

Вплив ДІП також може бути структурований як за типом інтервенцій ДІП (безпосереднє фінансування сталого розвитку, його Цілей, зокрема й нівелювання ризиків, що виникають у цьому процесі; створення сприятливого середовища для ВI), так і за цільовими секторами таких інтервенцій (табл. 2).

Таблиия 2

\section{Роль ДІП у межах фінансової системи сталого розвитку за секторами} економіки та її ключовими напрямами

\begin{tabular}{|c|c|c|}
\hline Папрями & Фінансовий сектор & Реальний сектор \\
\hline $\begin{array}{l}\text { Фінансування } \\
\text { сталого } \\
\text { розвитку } \\
\text { (нівелювання } \\
\text { ризиків) }\end{array}$ & $\begin{array}{l}\text { Гранти } \\
\text { Гарантії Довгострокові кредитні лінії } \\
\text { Відповідальні інвестиційні продукти } \\
\text { Урядові інвестиційні керівництва } \\
\text { (національний банк, пенсійний фонд) } \\
\text { Сприятливий податковий режим для } \\
\text { відповідальних інвестиційних продуктів }\end{array}$ & $\begin{array}{l}\text { Гранти } \\
\text { Прямі фіскальні стимули } \\
\text { Податкові виключення } \\
\text { Національні політики сталих } \\
\text { закупівель } \\
\text { Субсидіювання діяльності } 3 \\
\text { дослідження та розвитку (R\&D) }\end{array}$ \\
\hline $\begin{array}{l}\text { Створення } \\
\text { сприятливого } \\
\text { середовища } \\
\text { для ВI у } \\
\text { сталий } \\
\text { розвиток }\end{array}$ & $\begin{array}{l}\text { Забезпечення } \\
\text { можливостей } \quad \text { для } \quad \text { стейкхолдерів } \\
\text { фінансового сектору з урахуванням ESG } \\
\text { - критеріїв } \\
\text { Забезпечення даних для прийняття } \\
\text { відповідальних інвестиційних рішень }\end{array}$ & 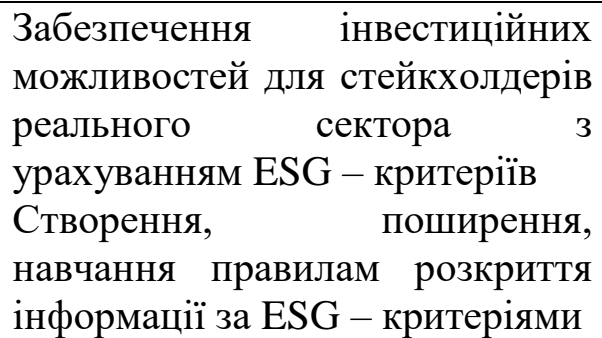 \\
\hline
\end{tabular}

Джерело: складено авторами за даними [45].

У межах інвестиційного ланцюга свої регуляторні функції в рамках визначеної ДІП держава реалізує через державний сектор економіки, і через спеціальні інститути - органи виконавчої влади та місцевого самоврядування, відповідні міністерства, відомства, фонди служби та Національний банк. Їхні повноваження в контексті ДІП наведено в табл. 3. 
Роль державних органів у реалізації ДІП засобами ВI

\begin{tabular}{|l|l|}
\hline \multicolumn{1}{|c|}{ Орган } & \multicolumn{1}{|c|}{ Специфіка повноважень у контексті ВI } \\
\hline $\begin{array}{l}\text { Міністерства розвитку } \\
\text { економіки, торгівлі та } \\
\text { сільського господарства } \\
\text { України }\end{array}$ & $\begin{array}{l}\text { Формування та виконання дорожніх карт і стратегій сталого } \\
\text { розвитку економіки, запровадження механізмів ВI у } \\
\text { державному секторі економіки }\end{array}$ \\
\hline $\begin{array}{l}\text { Національний банк } \\
\text { України }\end{array}$ & $\begin{array}{l}\text { Упровадження ризик-орієнтованого підходу з урахуванням } \\
\text { екологічних, соціальних викликів та ризику зміни клімату до } \\
\text { забезпечення монетарної стабільності і банківського нагляду }\end{array}$ \\
\hline $\begin{array}{l}\text { Національна комісія, що } \\
\text { здійснює державне } \\
\text { регулювання у сфері ринків } \\
\text { фінансових послуг }\end{array}$ & $\begin{array}{l}\text { Імплементація новітніх інвестиційних інструментів у сфері } \\
\text { страхування природних катастроф, критеріїв ВІ у сфері } \\
\text { недержавного пенсійного забезпечення }\end{array}$ \\
\hline $\begin{array}{l}\text { Національна комісія з } \\
\text { цінних паперів та } \\
\text { фондового ринку }\end{array}$ & $\begin{array}{l}\text { Розробка ринкових орієнтирів на основі ЕSG - критеріїв, } \\
\text { керівництв із розкриття інформації, концептуальних основ для } \\
\text { інвестиційного аналізу у сфері ВІ }\end{array}$ \\
\hline Фонд державного майна & Управління об’єктами приватизації з урахуванням критеріїв ВI \\
\hline Антимонопольний комітет & $\begin{array}{l}\text { Сприяння створенню конкурентного середовища на } \\
\text { інвестиційному ринку }\end{array}$ \\
\hline
\end{tabular}

Примітка. * до зміни моделі регулювання фінансового ринку.

Джерело: складено авторами.

Разом із тим, наведені підходи до визначення ролі ДІП у досягненні орієнтирів сталого розвитку засобами ВІ зводяться до обгрунтування значущості такої політики та окреслення ï базових напрямів. Однак, такі підходи позбавлені конкретики в розробці чітких дій державних органів щодо стимулювання ВI та їх прив'язки до національної і глобальної системи ЦСР.

Спроба картування ролі фінансових посередників, технологій і продуктів, зокрема й державних регуляторів у фінансовій системі нового типу, зорієнтованої на досягнення сталого розвитку відповідно до його конкретних Цілей наведена в дослідженні [46] за аспектами «доступу», «інвестування», «ризику» та наскрізного впливу (табл. 4).

Таблиия 4

Аспекти і заходи ДІП за ЦСР

\begin{tabular}{|c|c|c|}
\hline Аспект & Заходи ДІП & ЦСР \\
\hline Доступ & $\begin{array}{l}\text { Забезпечення фінансової інклюзії для всіх (Цілі 1, 2, 3, 4, 10), малих } \\
\text { і середніх підприємств (Цілі 5, 8) та урядів (Ціль 13) і забезпечення } \\
\text { ефективної алокації капіталу }\end{array}$ & $\begin{array}{l}\text { ЦСР } 1,2 \\
3,4,5,8, \\
10,13\end{array}$ \\
\hline Інвестування & $\begin{array}{l}\text { Інвестування у сферу відновлювальної енергетики (Цілі 7, 13) та } \\
\text { інші інфраструктурні проекти (Цілі 6, 9) }\end{array}$ & $\begin{array}{l}\text { ЦСР 6, } \\
7,9,13\end{array}$ \\
\hline Ризик & $\begin{array}{l}\text { Розвиток інноваційних моделей оцінювання, бізнесу, сталого } \\
\text { виробництва та споживання на основі ризик орієнтованого підходу } \\
\text { (Ціль 12); та інвестування в надійну інфраструктуру (Ціль 11) }\end{array}$ & $\begin{array}{c}\text { ЦСР 11, } \\
12\end{array}$ \\
\hline $\begin{array}{l}\text { Наскрізний } \\
\text { вплив }\end{array}$ & $\begin{array}{l}\text { Прийняття кращих принципів і практик для керівництва бізнес- } \\
\text { транзакціями та процесом інвестування } 3 \text { урахуванням ESG - } \\
\text { критеріїв, ризиків і можливостей }\end{array}$ & $\begin{array}{l}\text { ЦСР } 1 \\
14,15 \text {, }\end{array}$ \\
\hline
\end{tabular}

Джерело: складено авторами на основі [46]. 


\section{Agricultural and Resource Economics \\ www.are-journal.com}

Для усунення вказаних недоліків пропонуємо розгляд ролі ДІП та ВI як іiі механізму за різними підходами доповнити картуванням іiі напрямів та інструментарію ВІ за релевантними ЦСР та завданнями ООН, національними завданнями в досягненні цих Цілей та пріоритетними завданнями.

Для визначення переліку ESG-критеріями найбільш релевантних ЦСР та пріоритетних ESG-критеріїв пропонуємо звернути увагу на механізм залучення стейкхолдерів та відбір їх найбільш істотних запитів для ВІ як механізму ДІП. До прикладу, у результаті опитування 207 відповідальних інвесторів, 328 країн світу, проведеного у 2019 р. щодо ролі ЦСР та ESG - критеріїв у прийнятті інвестиційних рішень в інвестиціях були визначені такі релевантні Цілі та пріоритетні критерії (рис. 2).

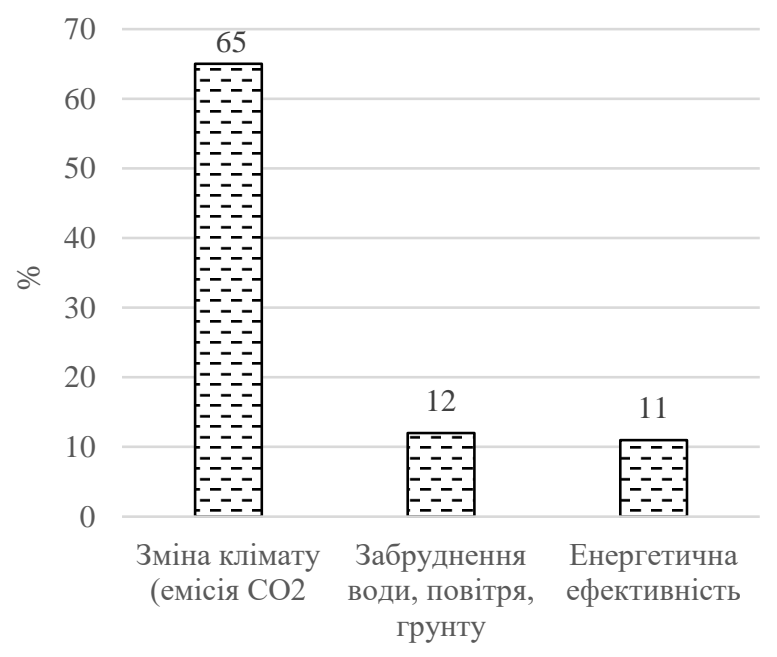

Екологічний критерій

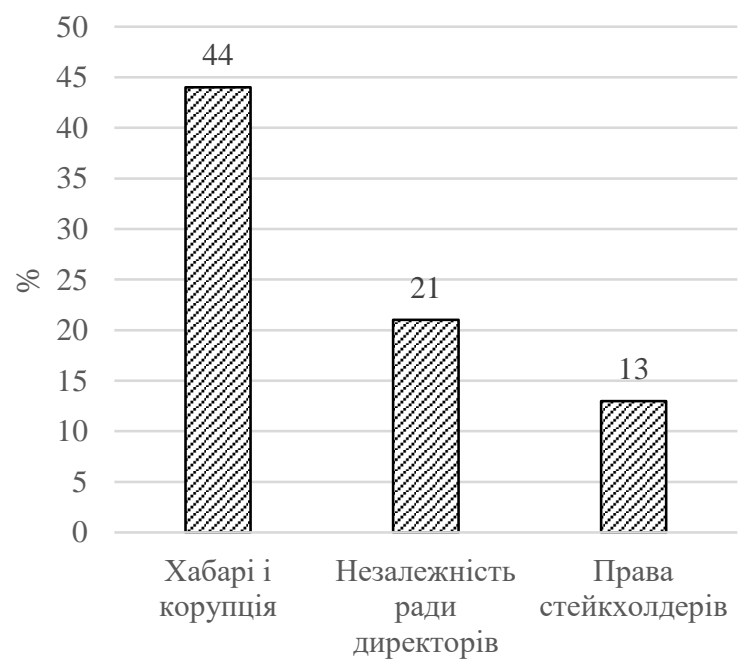

Управлінський критерій

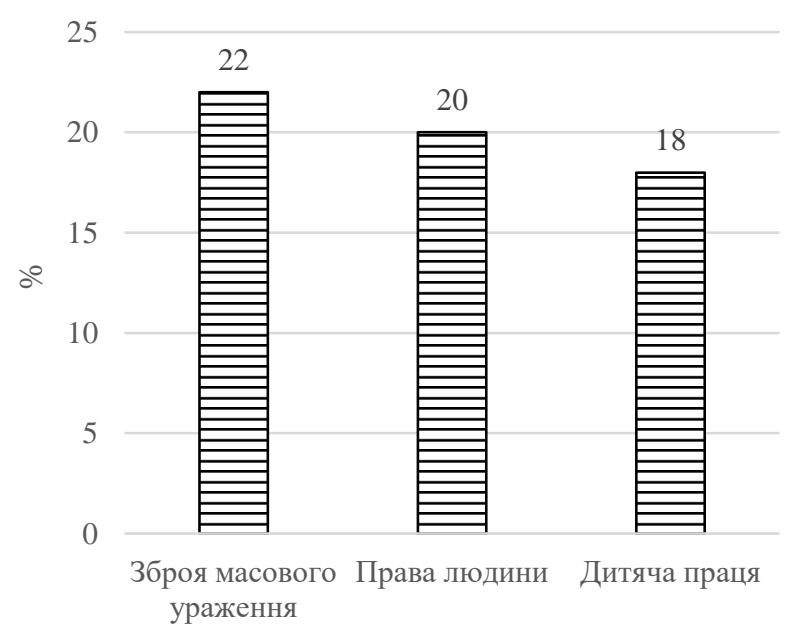

Соціальний критерій

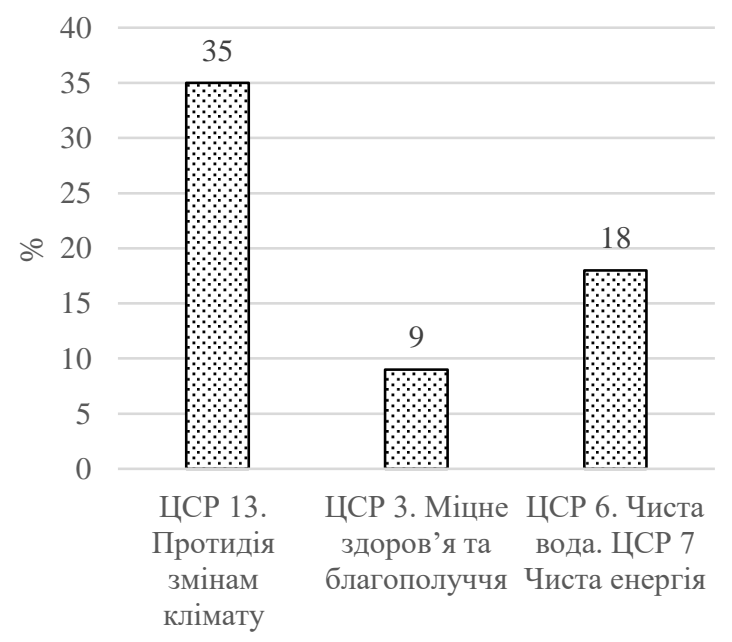

Цілі сталого розвитку

\section{Рис. 2. Важливість критеріїв та ЦСР для прийняття інвестиційних рішень інвесторами, \% від чисельності опитаних}

Джерело: складено авторами на основі [47].

Результати зазначеного опитування $\epsilon$ доволі показовими, оскільки демонструють пріоритетні сфери та напрями для розвитку BI серед кращих представників інвестиційної індустрії. Подібні опитування стейкхолдерів на 


\section{Agricultural and Resource Economics \\ www.are-journal.com}

національному рівні можуть бути використані як картування ДІП за найбільш релевантними національними завданнями ЦСР та пріоритизації ESG - критеріїв під час іiї реалізації.

Висновки. Формування нової ДІП, яка спирається на механізми ВI, є основою для переформатування фінансових систем країн світу на засадах сталого розвитку, з інкорпорованими ЦСР та ESG - критеріями у фінансові технології, інвестиційні продукти, стратегії інвестування приватних та інституційних інвесторів. Роль каталізатора цих процесів безпосередньо належить державі як «ініціатору», «медіатору» та «акумулятору» у сфері ВI. На основі цього розроблено дворівневий теоретико-методичний підхід до визначення ролі ДІП та місця механізму ВІ у формуванні фінансової системи, зорієнтованої на досягнення ЦСР, на першому рівні якого означена роль конкретизується за:

1) суб'єктами (Приватні та інституційні інвестори, Держава (в особі органів реалізації ДІП), Міжнародні фінансові, донорські та наглядові організації, Неурядові організації, Компанії, Громадськість);

2) стадіями (Мобілізація, Акумуляція, Трансмісія, Алокація інвестиційних ресурсів та Відшкодування вкладених інвестицій);

3) секторами (Домогосподарства, Реальний та Фінансовий сектори) інвестиційного ланцюга; на другому рівні - картування напрямів ДІП та інструментарію ВІ за релевантними ЦСР та завданнями ООН і національними завданнями в досягненні цих Цілей.

Таке структурування дає змогу в подальшому синтезувати функції ДІП як каталізатора інкорпорації ЦСР та ESG - критеріїв у традиційний інвестиційний ланцюг. Пріоритетність урахування ЦСР та ESG - критеріїв при прийнятті інвестиційних рішень і реалізації ДІП має базуватись на опитуваннях ключових категорій стейкхолдерів.

\section{Список використаних джерел}

1. United Nations Conference on Environment \& Development Rio de Janerio. URL: https://sustainabledevelopment.un.org/content/documents/Agenda21.pdf.

2. Sustainable Development. Johannesburg Plan of Implementation. URL: https://www.sustainabledevelopment2015.org/AdvocacyToolkit/index.php/earthsummit-history/historical-documents/94-jpoi.

3. General Assembly. The future we want. Resolution adopted by the General Assembly.

URL: https://www.un.org/ga/search/view_doc.asp?symbol=A/RES/66/288\&Lang=E.

4. Bielenberg A., Kerlin M., Oppenheim J., Roberts M. Financing change: How to mobilize privatesector financing for sustainable infrastructure. McKinsey Center for Business and Environment. 2016. 62 p. URL: http://www.indiaenvironmentportal.org.in/files/file/Financing_change_How_to_mobi lize_private-sector_financing_for_sustainable-_infrastructure.pdf.

5. Вигівська І. М., Хоменко Г. Ю., Шумило К. В. Соціально-відповідальне інвестування: сутність, ризики та перспективи розвитку. Проблеми теорії та 
методології бухгалтерського обліку, контролю і аналізу. 2017. Вип. 3. С. 3-7. https://doi.org/10.26642/pbo-2017-3(38)-3-76.

6. Дейч М. С. Становлення та розвиток багаторівневої системи соціальної відповідальності: управлінський аспект: монографія. Донецьк: Інститут економіки та промисловості, 2014. 352 с.

7. Антошко Т. Р. Механізм впровадження корпоративної соціальної відповідальності на промислових підприємствах: автореф. дис. ... канд. екон. наук. Київ, 2012. 20 с.

8. Огороднікова Н. Л. Механізм стимулювання соціальної відповідальності в системі управління підприємством: автореф. дис. ... канд. екон. наук. Маріуполь, 2014. 19 с.

9. Пересада А. А. Інвестування. Київ: КНЕУ, 2004. 249 с.

10. Максимова Т. В. Державний механізм інвестиційної політики в Україні: дис. ... канд. наук з держ. управління. Маріуполь, 2015. 291 с.

11. Федоров Г. О. Механізми державного регулювання залучення іноземних інвестицій: дис. ... канд. наук з держ. управл. Харків, 2019214 с.

12. Ільїна А. О. Державне регулювання інвестиційного процесу в Україні: автореф. дис. ... канд. екон. наук. Київ, 2017. 23 с.

13. Артемов С. Г. Державне стимулювання інвестиційних процесів в Україні: автореф. дис. ... канд. екон. наук. Чернігів, 2014. 20 с.

14. Плішка Т. П. Корпоративна соціальна відповідальність як різновид інноваційно-інвестиційних процесів. Університетські наукові записки. 2012. № 2. C. 230-235.

15. Ігнатенко М. М. Динаміка та взаємозв'язок капітальних інвестицій, прибутковості та рівнів соціальної відповідальності харчових підприємств України. Молодий вчений. 2015. № 6(21). Ч. 1. С. 99-104.

16. Рудейчук С. В. Тенденції розвитку соціально-відповідального інвестування в Україні: облікові засади. Проблеми теорії та методологіi бухгалтерського обліку, контролю $i$ аналізу. 2017. Вип. 2(37). С. 83-86. https://doi.org/10.26642/pbo-2017-2(37)-83-86.

17. Панченко Н. Г. Соціальні інвестиції як провідний інструмент корпоративної соціальної відповідальності. Вісник економіки транспорту $i$ промисловості. 2018. № 63. С. 241-247.

18. Шкура I. С. Роль соціально відповідального інвестування у забезпеченні сталого розвитку України. Економічний нобелівський вісник. 2016. № 1(9). C. 252-262.

19. Романьок Т. В. Відповідальне інвестування в транснаціональному бізнесі: автореф. дис. ... канд. екон. наук. Київ, 2014. 20 с.

20. Леус Д. В. Портфельне інвестування як інструмент фінансового забезпечення сталого розвитку економіки України: дис. ... канд. екон. наук. Суми, 2014. 268 с.

21. Петрашко Л. П. Стратегічні орієнтири формування соціально відповідального інвестування в Україні. Вісник Сумського державного 


\section{Agricultural and Resource Economics}

www.are-journal.com

університету. Серія: Економіка. 2014. № 3. С. 7-17.

22. Лазар Ю. Інвестиційний механізм розвитку соціальної відповідальності на засадах державно-приватного партнерства. Соціально-економічні проблеми $i$ держава. 2013. Вип. 2. С. 75-88.

23. Лазар Ю. В. Сучасні тренди розвитку соціально відповідального інвестування: закордонний та вітчизняний досвід. Mechanism of Economic Regulation. 2012. No. 4. Pp. 190-196.

24. Музиченко О. В. Сучасні світові тренди тематичного відповідального інвестування. Інвестийї: практика та досвід. 2015. № 20. С. 16-22.

25. Ari I., Koc M. Sustainable Financing for Sustainable Development: AgentBased Modeling of Alternative Financing Models for Clean Energy Investments. Sustainability. 2019. Vol. 11. No. 7. 1967. https://doi.org/10.3390/su11071967.

26. Ari I., Koc M. Sustainable Financing for Sustainable Development: Understanding the Interrelations between Public Investment and Sovereign Debt. Sustainability. 2018. Vol. 10. No. 11. 3901. https://doi.org/10.3390/su10113901.

27. Bose S., Dong G., Simpson A. The Role of Finance in Achieving Sustainability. The Financial Ecosystem. Palgrave Studies in Impact Finance. Cham: Palgrave Macmillan, 2019. Pp. 1-18. https://doi.org/10.1007/978-3-030-05624-7_1.

28. La Torre M., Trotta A., Chiappini H., Rizzello A. Business Models for Sustainable Finance: The Case Study of Social Impact Bonds. Sustainability. 2019. Vol. 11. No. 7. 1887. https://doi.org/10.3390/su11071887.

29. Ziolo M., Filipiak B. Z., Bąk I., Cheba K. How to Design More Sustainable Financial Systems: The Roles of Environmental, Social, and Governance Factors in the Decision-Making Process. Sustainability. 2019. Vol.11. No. 20.5604. https://doi.org/10.3390/su11205604.

30. Tseng M.-L., Tan P. A., Jeng S.-Y., Lin C.-W.R., Negash Y. T., Darsono S. N. A. C. Sustainable Investment: Interrelated among Corporate Governance, Economic Performance and Market Risks Using Investor Preference

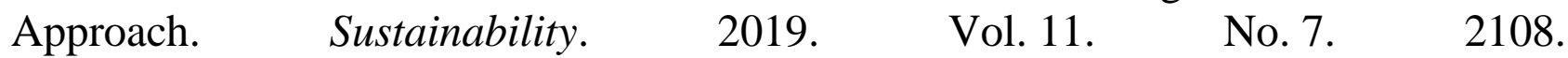
https://doi.org/10.3390/su11072108.

31. Méndez-Suárez M., Monfort A., Gallardo F. Sustainable Banking: New Forms of Investing under the Umbrella of the 2030 Agenda. Sustainability. 2020. Vol. 12. No. 5. 2096. https://doi.org/10.3390/su12052096.

32. Grzeszczyk T. A., Waszkiewicz M. Sustainable Investment Project Evaluation. Entrepreneurship and Sustainability Issues. 2020. Vol. 7. No. 3. Pp. 23632381. https://doi.org/10.9770/jesi.2020.7.3(60).

33. Sandberg J., Rönnegard D. Sustainable Investment: Mobilizing Financial Capital for Sustainable Development. Decent Work and Economic Growth. Encyclopedia of the UN Sustainable Development Goals. W. Leal Filho, A. Azul, L. Brandli, P. Özuyar, T. Wall eds. Cham: Springer, 2020. https://doi.org/10.1007/978-3-319-71058-7.

34. Blakstad S., Allen R. International Sustainable Investment. FinTech Revolution. Cham: Palgrave Macmillan, 2018. Pp. 215-226. 
https://doi.org/10.1007/978-3-319-76014-8_13.

35. Kew J., Krosinsky C. Dynamics Emerge on ESG and Sustainable Investment in China. Modern China. Cham: Palgrave Macmillan, 2020. Pp. 129-131. https://doi.org/10.1007/978-3-030-39204-8_11.

36. Camilleri M. A. Socially Responsible and Sustainable Investing. Corporate Sustainability, Social Responsibility and Environmental Management. Cham: Springer, 2017. Pp. 61-77. https://doi.org/10.1007/978-3-319-46849-5_4.

37. Bose S., Dong G., Simpson A. Sustainable Investing and Asset Allocation at Global Scale. The Financial Ecosystem. Palgrave Studies in Impact Finance. Cham: Palgrave Macmillan, 2019. Pp. 225-251. https://doi.org/10.1007/978-3-030-056247_10.

38. Financing a sustainable European economy. URL: https://ec.europa.eu/info/sites/info/files/170713-sustainable-finance-report_en.pdf.

39. The official site of the Swiss Sustainable Finance Initiative. URL: http://www.sustainablefinance.ch.

40. United Nations Environment Programme (UNEP) Inquiry. Sustainable Finance. A Critical Analysis of the Regulation, Policies, Strategies, Implementation and Reporting on Sustainability in International Finance. URL: http://wedocs.unep.org/handle/20.500.11822/7446?show=full.

41. Мельниченко О. А. Механізми реалізації інвестиційної політики держави. Теорія та практика державного управління. 2015. Вип. 1. С. 78-84.

42. EPSC Strategic Notes. Financing Sustainability Triggering Investments for the Clean Economy. URL: https://ec.europa.eu/epsc/sites/epsc/files/strategic_note_issue_25.pdf.

43. UN Global Compact, UNCTAD, UNEPFI, PRI. Private sector investment and sustainable development.

URL: https://www.unglobalcompact.org/docs/publications/Private_Sector_Investment_and _Sustainable_Development.pdf.

44. Investing in Sustainable Development Goals. Action Plan for Private Investments in SDGs. URL: https://unctad.org/en/PublicationsLibrary/osg2015d3_en.pdf.

45. Maimbo S. M., Zadek S. Roadmap for a sustainable financial system. UNEP Inquiry, World Bank Group. 2017. 104 p.

46. KPMG United Nations Global Compact. SDG Industry matrix. URL: https://www.unglobalcompact.org/library/3111.

47. ESG to SDGs: the road ahead. A survey of investors in alternatives. URL: https://www.lgtcp.com/shared/.content/publikationen/cp/esg_download/From-ESGto-SDGs_en.pdf.

\section{References}

1. United Nations Conference on Environment \& Development Rio de Janerio (1992), available at: https://sustainabledevelopment.un.org/content/documents/Agenda21.pdf. 


\section{Agricultural and Resource Economics}

www.are-journal.com

2. Sustainable Development (2015), Johannesburg Plan of Implementation, available

at:

https://www.sustainabledevelopment2015.org/AdvocacyToolkit/index.php/earthsummit-history/historical-documents/94-jpoi.

3. General Assembly. The future we want. Resolution adopted by the General Assembly, available

at: https://www.un.org/ga/search/view_doc.asp?symbol=A/RES/66/288\&Lang=E.

4. Bielenberg, A., Kerlin, M., Oppenheim, J. and Roberts, M. (2016), Financing change: How to mobilize privatesector financing for sustainable infrastructure. McKinsey Center for Business and Environment, available at: http://www.indiaenvironmentportal.org.in/files/file/Financing_change_How_to_mobi lize_private-sector_financing_for_sustainable-_infrastructure.pdf.

5. Vygivska, I. M., Khomenko, G. Yu., Shumylo, K. V. (2017), Social responsible investment: satisfaction, risks and prospects of development. Problems of Theory and Methodology of Accounting, Control and Analysis, vol. 3, pp.3-7, available at: http://dx.doi.org/10.26642/pbo-2017-3(38)-3-7.

6. Dejch, M. Je. (2014), Stanovlennja ta rozvytok baghatorivnevoji systemy socialjnoji vidpovidaljnosti: upravlinsjkyj aspect [The formation and development of a multilevel system of social responsibility: a managerial aspect], Donetsk: Industrial Economics Institute, Ukraine.

7. Antoshko, T. R. (2012), The mechanism of introduction of corporate social responsibility at industrial enterprises, Abstract of $\mathrm{Ph}$. D. dissertation, Economy and management of enterprises (by types of economic activity), Kyiv Polytechnic Institute, Kyiv, Ukraine.

8. Ohorodnikova, N. L. (2014), Mechanism of stimulation of social responsibility in the enterprise management system, Abstract of $\mathrm{Ph}$. D. dissertation, Economy and management of enterprises (by types of economic activity), Pryazovskyi State Technical University, Mariupol, Ukraine.

9. Peresada, A. A. (2004), Investuvannja [Investing], KNEU, Kyiv, Ukraine.

10. Maksymova, T. V. (2015), State mechanism of investment policy in Ukraine, $\mathrm{Ph}$. D. Thesis, Mechanisms of public administration, Donetsk State University of Management, Mariupol, Ukraine.

11. Fedorov, G. O. (2019), Mechanisms of state regulation of attraction of foreign, Ph. D. Thesis, Mechanisms of public administration, Kharkiv Regional Institute of Public Administration of the National Academy of Public Administration Attached to the Office of the President of Ukraine, Kharkiv, Ukraine.

12. Ilina, A. O. (2017), State regulation of the investment process in Ukraine, Abstract of Ph. D. dissertation, Economics and management of the national economy, Kyiv National University of Trade and Economics, Kyiv, Ukraine.

13. Artemov, S. G. (2014), State stimulation of investment processes in Ukraine, Abstract of Ph. D. dissertation, Economics and management of the national economy, Chernihiv National University of Technology, Chernihiv, Ukraine.

14. Plishka, T. P. (2012), Corporate Social Responsibility as a Type of Innovation 
and Investment Processes. Universytetsjki naukovi zapysky, vol. 2, pp. 230-235.

15. Ihnatenko, M. M. (2015), Dynamics and interrelation of capital investments, profitability and levels of social responsibility of the food enterprises of Ukraine. Young Scientist, vol. 6(21), part 1, pp. 99-104.

16. Rudejchuk, S. V. (2017), Trends of development of social responsible investment in Ukraine: accounting principles. Problems of theory and methodology of accounting, control and analysis, vol. 2(37), pp. 83-86. https://doi.org/10.26642/pbo2017-2(37)-83-86.

17. Panchenko, N. G. (2018), Social investment as a leading instrument of corporate social responsibility. The bulletin of transport and industry economics, vol. 63, pp. 241-247.

18. Shkura, I. S. (2016), The role of socially responsible investment in ensuring sustainable development of Ukraine. Economic Nobel Herald, vol. 1(9), pp. 252-262.

19. Romanjok, T. V. (2014), Responsible investing in transnational business, Abstract of Ph. D. dissertation, World economy and international economic relations, Kyiv National Economic University named after Vadym Hetman, Kyiv, Ukraine.

20. Leus, D. V. (2014), Portfolio investment as a tool for financial support for sustainable development of the Ukrainian economy, $\mathrm{PhD}$ Thesis, Money, finance and credit, State Higher Educational Institution «Ukrainian Academy of Banking», Sumy, Ukraine.

21. Petrashko, L. P. (2014), Strategic guidelines for the formation of socially responsible investment in Ukraine. Visnyk of Sumy State University. Economy series, тщ. 3, pp. 7-17.

22. Lazar, Ju. (2013), Investment mechanism of social responsibility development on the basis of public-private partnership. Socio-Economic Problems and the State, vol. 2, pp. 75-88.

23. Lazar, Ju. V. (2012), Current Trends in the Development of Socially Responsible Investment: Foreign and Domestic Experience. Mechanism of Economic Regulation, vol. 4, pp. 190-196.

24. Muzychenko, O. V. (2015), Current global trends in thematic responsible investing. Investyciji: praktyka ta dosvid, no. 20, pp. 16-22.

25. Ari, I. and Koc, M. (2018), Sustainable Financing for Sustainable Development: Understanding the Interrelations between Public Investment and Sovereign Debt. Sustainability, vol. 10, no. 11, 3901. https://doi.org/10.3390/su10113901.

26. Ari, I. and Koc, M. (2019), Sustainable Financing for Sustainable Development: Agent-Based Modeling of Alternative Financing Models for Clean Energy Investments. Sustainability, vol. 11, no. 7, 1967. https://doi.org/10.3390/su11071967.

27. Bose, S., Dong, G. and Simpson, A. (2019), The Role of Finance in Achieving Sustainability in The Financial Ecosystem. Palgrave Studies in Impact Finance. Palgrave Macmillan, Cham, Switzerland. https://doi.org/10.1007/978-3-030-056247_1. 


\section{Agricultural and Resource Economics}

www.are-journal.com

28. La Torre, M., Trotta, A., Chiappini, H. and Rizzello, A. (2019), Business Models for Sustainable Finance: The Case Study of Social Impact Bonds. Sustainability, vol. 11, no. 7, 1887. https://doi.org/10.3390/su11071887.

29. Ziolo, M., Filipiak, B. Z., Bąk, I. and Cheba, K. (2019), How to Design More Sustainable Financial Systems: The Roles of Environmental, Social, and Governance Factors in the Decision-Making Process. Sustainability, vol. 11, no. 20, 5604. https://doi.org/10.3390/su11205604.

30. Tseng, M.-L., Tan, P. A., Jeng, S.-Y., Lin, C.-W.R., Negash, Y. T. and Darsono, S. N. A. C. (2018), Sustainable Investment: Interrelated among Corporate Governance, Economic Performance and Market Risks Using Investor Preference Approach. Sustainability, vol. 11, no. 7, 2108. https://doi.org/10.3390/su11072108.

31. Méndez-Suárez, M., Monfort, A. and Gallardo, F. (2020), Sustainable Banking: New Forms of Investing under the Umbrella of the 2030 Agenda. Sustainability, vol. 12, no. 5, 2096. https://doi.org/10.3390/su12052096.

32. Grzeszczyk, T. A. and Waszkiewicz, M. (2020), Sustainable Investment Project Evaluation. Entrepreneurship and Sustainability Issues, vol. 7, no. 3, pp. 2363-2381. https://doi.org/10.9770/jesi.2020.7.3(60).

33. Sandberg, J. and Rönnegard, D. (2020), Sustainable Investment: Mobilizing Financial Capital for Sustainable Development in Decent Work and Economic Growth. Encyclopedia of the UN Sustainable Development Goals, eds W. Leal Filho, A. Azul, L. Brandli, P. Özuyar, T. Wall. Springer, Cham, Switzerland. https://doi.org/10.1007/978-3-319-71058-7.

34. Blakstad, S. and Allen, R. (2018), International Sustainable Investment in FinTech Revolution. Palgrave Macmillan, Cham, Switzerland. https://doi.org/10.1007/978-3-319-76014-8_13.

35. Kew, J. and Krosinsky, C. (2020), Dynamics Emerge on ESG and Sustainable Investment in China in Modern China. Palgrave Macmillan, Cham, Switzerland. https://doi.org/10.1007/978-3-030-39204-8_11.

36. Camilleri, M. A. (2017), Socially Responsible and Sustainable Investing in Corporate Sustainability, Social Responsibility and Environmental Management. Springer, Cham, Switzerland. https://doi.org/10.1007/978-3-319-46849-5_4.

37. Bose, S., Dong, G. and Simpson, A. (2019), Sustainable Investing and Asset Allocation at Global Scale in The Financial Ecosystem. Palgrave Studies in Impact Finance. Palgrave Macmillan, Cham, Switzerland. https://doi.org/10.1007/978-3-03005624-7_10.

38. Financing a sustainable European economy, (2017), available at: https://ec.europa.eu/info/sites/info/files/170713-sustainable-finance-report_en.pdf

39. The official site of the Swiss Sustainable Finance Initiative, available at: http://www.sustainablefinance.ch

40. United Nations Environment Programme (UNEP) Inquiry. (2016), Sustainable Finance. A Critical Analysis of the Regulation, Policies, Strategies, Implementation and Reporting on Sustainability in International Finance, available at: http://wedocs.unep.org/handle/20.500.11822/7446?show=full. 


\section{Agricultural and Resource Economics \\ www.are-journal.com}

41. Melnychenko, O. A. (2015), Mechanisms of realization of the state investment policy. Teorija ta praktyka derzhavnogho upravlinnja, vol. 1, pp. 78-84.

42. EPSC Strategic Notes (2017), Financing Sustainability Triggering Investments for the Clean Economy, available at: https://ec.europa.eu/epsc/sites/epsc/files/strategic_note_issue_25.pdf.

43. UN Global Compact, UNCTAD, UNEPFI, PRI (2015), Private sector investment and sustainable development, available at: https://www.unglobalcompact.org/docs/publications/Private_Sector_Investment_and _Sustainable_Development.pdf.

44. Investing in Sustainable Development Goals. Action Plan for Private Investments in SDGs (2015), available at: https://unctad.org/en/PublicationsLibrary/osg2015d3_en.pdf.

45. Maimbo, S. M. and Zadek, S. (2017), Roadmap for a sustainable financial system. UNEP Inquiry, World Bank Group, available at: http://unepinquiry.org/publication/roadmap-for-a-sustainable-financial-system.

46. KPMG United Nations Global Compact (2015), SDG Industry matrix, available at: https://www.unglobalcompact.org/library/3111.

47. ESG to SDGs: the road ahead. A survey of investors in alternatives (2019), available at: https://www.lgtcp.com/shared/.content/publikationen/cp/esg_download/From-ESGto-SDGs_en.pdf.

How to cite this article? Як цитувати цю статтю?

Стиль - ДСТУ:

Пластун О., Сльнікова Ю., Шелюк А., Воронцова А., Артеменко А. Роль державної інвестиційної політики та відповідального інвестування у фінансуванні сталого розвитку. Agricultural and Resource Economics. 2020. Vol. 6. No. 2. C. 108-125. URL: http://are-journal.com.

Style - Harvard:

Plastun, A., Yelnikova, Y., Shelyuk, A. Vorontsova, A. and Artemenko, A. (2020), The role of public investment policy and responsible investment in sustainable development financing. Agricultural and Resource Economics, vol. 6, no. 2, pp. 108125, available at: http://are-journal.com. 